\title{
Hrvatski novocrkvenoslavenski jezik u 19. stoljeću (Početak jezične obnove na primjeru domisalskih izdanja Dragutina Antuna Parčića)
}

\begin{abstract}
S obzirom na dosad jasno istaknute i u literaturi utvrđene značajke o jezičnoj politici i primijenjenoj jezičnoj praksi u obnovi liturgijskih knjiga te o glagoljaškoj tradiciji u 19. stoljeću, cilj je rada bio ustvrditi obujam i kvalitetu doprinosa Dragutina A. Parčića u njihovu oblikovanju i provedbi. Kratkom komparativnom analizom predstavljene su grafetičke i grafemičke posebnosti prvoga domisalskog izdanja Dragutina A. Parčića Mrtvačka misa s koralnim napjevom iz 1860. (u odnosu na istu tekstualnu dionicu u Parčićevu misalu iz 1893. i Vajsovu misalu iz 1927.). Riječ je o litografskom otisku mrtvačke mise, koji se osobitostima slovopisa i pravopisa oslanja na izdanja Ivana Berčića (prvi zamah obnove istočnoslaveniziranih liturgijskih izdanja, tradiranje istočne novocsl. norme), u čijem je priređivanju sudjelovao i Parčić (Chrestomathia linguae vetero-slovenicae charactere glagolitico, Prag 1859.; Ulomci Sv. pisma, Prag 1865. - 1971.).

Analizom su se potvrdila neka načela Parčićeve jezične koncepcije, ponajprije konzervativnost i artificijelnost (kombinacija ocsl., hcsl. i istočnih novocsl. rješenja). Koncepcija je to koja se čak 30 godina prije izdanja Misala ovjerava izvornom i Parčiću prepoznatljivom, jedino što se konkretna rješenja razlikuju. Ta različita rješenja u Misi (1860., ali i 1864.) i Misalu (1893.) osnažuju, premda na drugačiji način (grafetička i grafemička razina, odnosno razina slovopisne/pravopisne i fonološke norme), istu prirodu Parčićeve jezične koncepcije.
\end{abstract}

\section{Uvodno i metodološki}

U hrvatskoj je filologiji danas neosporno da vodeća uloga u obnovi staroslavenskih liturgijskih knjiga na hrvatskom nacionalnom prostoru u 19. stoljeću pripada Dragutinu Antunu Parčiću. Taj je devetnaestostoljetni homo universalis u paleoslavističkoj/paleokroatističkoj literaturi poznat kao onaj koji je glagoljskim misalom spasio starodrevnu hrvatsku povlasticu-glagoljicu od neminovne propa$s t i^{1}$, koja joj je prijetila u drugoj polovini 19. stoljeća. Parčićeva se obnoviteljska uloga uklapa u proces obnove ćirilometodske baštine među Slavenima, koji je

Usp. BONEFAČIĆ 1903; BOLONIĆ 1972: 418-438. 
potaknuo biskup Josip Juraj Strossmayer odmah nakon stupanja na đakovačku i srijemsku biskupsku stolicu (1859. upućuje Promemoriju papi Piju IX., u kojoj zahtijeva tiskanje novih glagoljskih liturgijskih knjiga ${ }^{2}$, kao i u tada mladu hrvatsku ćirilometodsku znanost -Cyrillomethodianu, kojoj temelje postavlja povjesničar i filolog Franjo Rački ${ }^{3}$, a koje su za jedan od svojih temeljnih ciljeva istaknule povratak crkvenoslavenskoga jezika u liturgijsku upotrebu. Naime, stanje u kojemu su se našle liturgijske staroslavenske knjige u 19. stoljeću, kada glagoljica na području hrvatskih zemalja živi svojim potisnutim životom, može se opisati dvama problemima: nefunkcionalnošću postojećih i nedostatkom novih liturgijskih knjiga. Oba su navedena problema ozbiljno ugrozila opstanak staroslavenske liturgije na područjima na kojima je ona bila povijesno zajamčena (biskupije u austrijskoj Dalmaciji), istovremeno ugrožavajući i mogućnost njezina proširenja izvan granica tih područja (Zagrebačka te Đakovačka ili Bosanska i Srijemska biskupija), što će biti jednom od temeljnih tendencija u hrvatskoj Crkvi u drugoj polovini 19. stoljeća. Uzroke takvom stanju ponajprije valja tražiti u procesu istočnoslavenizacije liturgijskih knjiga za Slavene osnutkom Kongregacije za širenje vjere (1622.) u Rimu.

Odbor za izradu liturgijskih knjiga ${ }^{4}$, osnovan nakon što je Sveta Solica 1868. biskupu Strossmayeru povjerila rad na izradi liturgijskih knjiga na slavenskom jeziku, obnovu je glagoljskih knjiga najprije povjerio zadarskom profesoru i glagoljašu Ivanu Berčiću. ${ }^{5}$ Budući da Berčić iznenada umire 1870., izbor pada na franjevca trećoreca Dragutina Antuna Parčića. U njegovu je korist zasigurno presudila bogata glagoljaška prošlost, koja se razvijala smjerom Vrbnik - Glavotok - Zadar. Mihovil će Bolonić za Parčića reći da je već s majčinim mlijekom usisao ljubav za glagoljicu i glagoljsku stvar. ${ }^{6}$ Rođen u staroj glagoljaškoj Krčkoj biskupiji, u Vrbniku na otoku Krku, još je kao dječak služio pri misama brojnim glagoljašima u vrbničkoj plovanskoj crkvi. Njegovo se napredovanje najprije nastavlja u krugu redovnika glagoljaša na Glavotoku, gdje je iskusio da glagoljaše tišti nedostatak liturgijskih priručnih knjiga, a onda u višim latinskim školama u Zadru, kamo dolazi 1843. Ondje na njega značajan utjecaj ostavljaju dvojica glagoljaša: redovnički subrat o. Benedikt Mihaljević, koji je od 1823. do 1855. bio profesor staroslavenskoga i hrvatskoga jezika u tamošnjem nadbiskupskom bogoslovnom sjemeništu i koji ga je pripremao za svoga nasljednika

\footnotetext{
$2 \quad$ LUKIĆ I KREZIĆ 2014: 211.

3 PETROVIĆ 1979: 47-99.

4 Članovima toga odbora bili su: biskup Strossmayer, Franjo Rački, Mihovil Pavlinović, Ivan Brčić, Vatroslav Jagić i Đuro Daničić (LUKIĆ I PILJ TOMIĆ 2010: 83).

5 LUKIĆ I PILJ TOMIĆ 2010: 83.

6 BOLONIĆ 1973: 418.
} 
na staroslavenskoj katedri, te spomenuti Ivan Berčić. Potonjemu, kojega je Jagić nazvao uskrisiteljem glagoljice u Dalmaciji, Parčić će pomagati u znanstvenome radu, ponajprije u sastavljanju knjige Chrestomathia linguae vetero-slovenicae charactere glagolitico (Prag 1859., 1864.) te prikupljanju i priređivanju građe za tri knjige Ulomaka Sv. pisma (Prag 1865. - 1871.), pekući tako zanat za svoje buduće poslanje u procesu jezične i pismovne obnove hrvatskoglagoljskih liturgijskih knjiga u 19. stoljeću. ${ }^{7}$

Iako je kruna Parčićeve jezičnoliturgijske obnove, ali i hrvatske Cyrillomethodiane u cjelini glagoljski Misal, objelodanjen 1893. - Rimbski Misalb slavênbskimb ezikomb presv. G. N. Urbana Papi VIII povelêniemb izdanbMissale Romanum slavonico idiomate ex decreto sacrosancti Concilii Tridentini (Rim, Congr. de Propaganda Fide, 1893.), pri definiranju njegove jezične koncepcije valja uzeti u obzir i samostalna liturgijska izdanja koja je priredio prije Misala:

- obrazac mise Misi za umr 'šee s koralnim napjevom (litografija, Galevac 1860.)

- obrazac mise za Kêsara i Kralja našego i Decretum (litografija, Zadar prije 1863.)

- obrazac mise na blagdan Bezgrešnoga začeća (litografija, Krk 1. prosinca 1864.)

- napjev za kor Vsa lêpa esi, Marie s koralnim notama (iza glavnoga oltara u crkvi Sv. Marije na Glavotoku)

- prijevodi himna Jam lucis orto sidere pod naslovom PESSAN (tiskani u Serafinskoj tiskari u Glavotoku 1870 -ih) ${ }^{8}$

- Čin i Pravilo misi ošće že i molitvi pre i po mise iz'Rim śkago misala (Rim 1881.)

- Prilog'slovên'skim'ezikom'v'nem 'že misi v'seob'ĉee vr'k've, za nêkaê mêsta i v'tretiem' činê sv. Fran'čiska služimie s'dr'žet'se (Rim 1881. i dr.). ${ }^{9}$

U tim su izdanjima posvjedočene razvojne etape u procesu planiranja statusa i korpusa hrvatskoga novocsl. jezika, a obično se ističe kako funkcioniraju kao svojevrsna spona s razdobljem istočnoga novocsl. jezika jer i Berčić i Parčić do probnih otisaka 1881. čuvaju naslijeđenu istočnu novocsl. slovopisnu i pravo-

7 JAGIĆ 1910: 288-300; TANDARIĆ 1993: 78-84; HERCIGONJA 2004: 165; LUKIĆ I PILJ TOMIĆ 2010: 75-107; LUKIĆ 2012: 317-337.

8 Prvi stih: Se svita zvizdi v'sijavši te Adoro te devote latens Deitas Tome Akvinskoga, a naslov SLOG sv. Tomi iz'Akvina k'sv. Evharistii s prvim stihom Nic'ti se klanam, Božestvo tajnoe.

9 Usp. BADURINA 1993: 155-182. 
pisnu normu ${ }^{10}$, uz jezičnu kroatiziranost teksta. ${ }^{11}$ Razvoj i obnova hcsl. jezika u 19. stoljeću bili su postupni upravo zbog činjenice da se jezik ciljao normirati zadovoljavanjem izvanjezičnih tendencija $-\mathrm{s}$ jedne strane nacionalnoznačajnih (obnoviteljskih), a s druge unionističkih (nadnacionalnih, sveslavenskih). ${ }^{12}$ Osnovni je zadatak ovoga rada predstaviti neke elemente usporedne grafemičke analize Parčićeva litografskoga izdanja Mise za umrle (1860.) i istoga teksta u Misalu (1893.), s ciljem utvrđivanja:

10 Poznato je da Berčić u svojim izdanjima čuva dijakritičke znakove koje je uveo Karaman (npr. jat bez točkice za /ja/, jat s točkicom za /je/, jat $\mathrm{s}$ dijakritičkim znakom (/ja/ <*ocsl. /ę/), slovo $i$ kojim se bilježi /i/, slovo $i$ kojim se bilježi /i/ ispred vokala $\mathrm{i} / \mathrm{j} /$, slovo $i$ kojim se bilježi /j/, slovo $i$ za jeri itd.). Riječ je o grafijskim rješenjima koja zadovoljavaju moderne filologe s kraja 19. stoljeća jer daju informacije o jezičnoj prošlosti i etimologiji. Mi smo zbog toga istaknuli da istočna novocsl. izdanja Parčiću služe kao sigurnosni predložak u restauraciji jezične starine. U nastavku rada donose se primjeri transliterirani prema standardiziranim transliteracijskim normama. Od njih smo odstupili samo prilikom bilježenja istočnih novocsl. utjecaja: štapića za jerove (kako bismo upozorili da Parčić u domisalskim izdanjima tradira istočnu novocsl. slovopisnu i pravopisnu normu), jata bez točkice i s točkicom, slova $i$ kojim se bilježi $/ \mathrm{i} /, / \mathrm{j} /$ itd.

11 Usp. TANDARIĆ 1993: 81. Konkretna analiza slovnoga inventara Par. litografskoga otiska Mise (1860.) pokazat će da nisu uvijek tradirana istočna novocsl. slovna rješenja, već naprotiv (npr. bilježenje jerija digrafom/dvoslovom). Primjeri nasljedovana istočnoga novocsl. slovopisa i pravopisa: slovo $i$ s dijakritikom - bilježenje glasa /j/: Pokǒ /pokoj/ (Par. 1) : Pokoi (Par. 78a) : Pokoŭ (Kar. LXXVa) : Pokoj (Vajs 90a), darŭ /daruj/ (Par. 1) : darui (Par. 78a) : darŭ (Kar. LXXVa) : daruj (Vajs 90a), Razboinnika /Razbojnika/ (Par. 6) : razboiniku (Par. 79a) : razbojniku (Vajs 91b). Glas /j/ u međuvokalnom položaju ne bilježi se ovim slovom: moguće je da nema zabilježenoga hijatskog /j/ ili da je zabilježen s pomoću prejotiranoga slova ju, odnosno slova $\hat{e}$ (kad je riječ o glasovnoj skupini /ja/). U međuvokalnom položaju ispred slova $e$ ne bilježi se slovo za glas /j/ (usp. Prvotisak 1483.): podobaeti (Par. 1) : podobaetb (Par. 78a) : podobajet (Vajs 90a), otıvêcaetí (Par. 5) : otvêcaetb (Par. 78b) : otvěćajet (Vajs 91a). Također, između slova za vokale $o$ i $i$ ne bilježi se slovo za glas $/ \mathrm{j} /:$ ne uboitı (Par. 3) : ne uboitb (Par. 78b) : ne uboit (Vajs 91a). Ispred slova za vokale /u/ i /a/ bilježi se glas /j/ kao sastavnica prejotiranih slova jat i ju: moju (Par. 1) : тојu (78a) : moju (Vajs 90a), vêćínoju (Par. 2) : vêčsnuju (Par. 78b) : věčnuju (Vajs 91a), blagodatiju tvoeju (Par. 4) : blagodêtiju tvoeju (Par. 78b) : blagodětju tvojeju (Vajs 91a). Zabilježena je i jedna pogreška u Misi (1860.): Marĭju (Par. 6) umjesto Mariju, analogijom prema Karamanovu bilježenju slova ïže u oblicima imenice Marija (pisanje slova $i z ̌ e$ pred slovima za vokale $a, i, j u$ ): $\ddot{i}$ s nadrednom točkicom u obliku Marï-ju (BABIČ 2000: 105).

12 Upozoravamo da se u radu kraticama označuju crkvenoslavenski idiomi: ocsl. = opće(crkveno) slavenski književni jezik (jezik kanonskih tekstova), hcsl. jezik = hrvatski crkvenoslavenski jezik (od 12. do 16. stoljeća), novocsl. jezik = novocrkvenoslavenski jezik, javlja se u određenoj sredini usporedno s književnim jezikom kojemu je osnova narodni, domaći idiom (usp. DAMJANOVIĆ 2005: 11). Postoje dvije inačice novocrkvenoslavenskoga jezika: istočni novocsl. jezik, odnosno istočni novocrkvenoslavenski jezik (17. i 18. stoljeće), te hrvatski novocsl. jezik, odnosno hrvatski novocrkvenoslavenski jezik 19. i 20. stoljeća (početkom 20. stoljeća izdanja J. Vajsa, krajem 20. stoljeća J. L. Tandarića, usp. Rimski misal... ČIN MISI s izbranimi misami 1980; MIHALJEVIĆ 2009: 289). S obzirom na to da je posljednjim dvjema inačicama zajednička umjetna, knjiška osnovica, u radu ih označavamo i kraticama: istočni novocsl. jezik $=$ istočni novocrkvenoslavenski jezik, hrvatski novocsl. jezik = hrvatski novocrkvenoslavenski jezik. 
- grafemičkih osobitosti (slovni inventar i višestrukosti te ostale distinktivne grafičke jedinice pisanoga jezika) u Parčićevim domisalskim izdanjima (oprimjereno na Misi za umrle iz 1860.) . $^{13}$

- sličnosti i razlika prema Misalu (1893. $)^{14}$ ali i istočnoslaveniziranim izdanjima (Brevijar 1648., Misal 1741., Brevijar 1791.), kanonskim te primjernim spomenicima hosl. jezika (Misal 1483.)

- početnih tendencija pismovne i jezične restauracije hcsl. jezika u 19. stoljeću u odnosu prema dovršenoj jezičnoj koncepciji provedenoj u Misalu (1893., uzorna hcsl. norma 19. stoljeća).

U metodološkom smo smislu osobito važnim držali združivati poglavlja koja se u dosadašnjim radovima uglavnom donose pojedinačno (poglavlje o grafiji i poglavlje o fonologiji/glasovima) jer smatramo da, potaknute pristupom Matea Žagara (2007.), nije dokraja moguće odvojiti njihove međuutjecaje i međuovisnost. Zabilježena slova, kao pismovni oblici najmanjih jezičnih jedinica, i njihov odraz prema izgovorenoj jezičnoj strani predmet su izučavanja grafemike, kao discipline podređene grafematici. Autori priručnika Lexikon der germanitischen Linguistik (Tübingen 1973.), H. P. Althaus, H. Henne i H. E. Wiegand, grafemiku definiraju kao znanost o distinktivnim grafičkim jedinicama pisanoga jezika (i to ne samo grafemima, kao pismovnim jedinicama koje odgovaraju najmanjoj jezičnoj jedinici). ${ }^{15}$ Ona odgovara fonemici kao znanosti o razlikovnim foničkim elementima govornoga jezika. U našem je slučaju osobito zanimljivo ukazati na to da slovni inventar i vizualan izgled otiska (grafetički podaci) svjedoče jedno (oslonjenost na jednu tradiciju u Parčića), a bilježenje glasovnih promjena (npr. zamjene, vokalizacija ili ispadanje) mogu svjedočiti drugo (oslonjenost na drugu tradiciju u Parčića).

\begin{tabular}{|lll|}
\hline & Usmenost & Pismenost \\
\hline Jezik & fonematika /fonem/ & grafematika $/$ grafem/ \\
\hline Govor & fonetika /fon/glas/ & grafetika $/$ graf/ \\
\hline
\end{tabular}

Tablica 1. Dihotomija usmenost : pismenost / jezik : govor ${ }^{16}$

Misi za umrbšee (Par. 1-12). Stranice su numerirane glagoljičnim slovima u brojevnoj vrijednosti, a tekst prati notni zapis.

14 Misi za umrb̌̌ee (Par. 78a-84b), Misi za umršeje (Vajs 90a-96b).

15 Usp. ŽAGAR 2007: 31-32.

16 Isto: 32. 


\section{Grafetičke i grafemičke posebnosti Mise za mrtve}

\section{Jerovi}

Uvidom u Parčićevu Misu za mrtve iz 1860. došli smo do novih saznanja o slovima za jerove. Ona su, dakako, odraz naslijeđene istočnoslavenizirane Karamanove tradicije, pa se razlikuje štapić za jor i štapić s dijakritičkim znakom za jer. Međutim, gotovo nepogrešiva distribucija slova za slabe i jake jerove iznova svjedoči o načelima jezičnoga ,obnavljanja“ postojećih izdanja s obzirom na ocsl. normu (izvornu staroslavensku normu, vidi i restauracijsku tendenciju istočnih novocsl. izdanja). No, obnavljanje u tom smislu ne znači samo revitalizaciju izvorne hcsl. norme, već i ugledanje na spomenike ocsl. kanona te na istočnoslavenizirane spomenike. Djelovanje prema načelima nove koncepcije (umjetna, knjiška norma) podrazumijeva da se od dosadašnjih tradicija uzima najbolje i stavlja u ravnotežu: jednom su to rješenja kanonskih spomenika, drugi put ona s početaka redakcijskih formiranja, ali i rješenja iz hrvatskoglagoljskih rukopisa i tiskanih izdanja 14. i 16. stoljeća, a treći su put to rješenja istočnoslaveniziranih izdanja (na različit način u Misi iz 1860., gdje Parčić razlikuje slova za jorove i jerove prema Karamanu, a na različit način u Misalu iz 1893. gdje ostavlja slovo e za karakterističnu istočnoslaveniziranu vokalizaciju: denesb, otecb). ${ }^{17}$

Usporedbom sa stanjem u Misalu 1893. i Misi za umrle 1860. zaključuje se kako je u odnosu na bilježenje slova za nekadašnje slabe jerove uočena veća pravilnost (u odnosu na uzornu staroslavensku normu) u litografskom izdanju Mise iz 1860. ${ }^{18}$ Vajsovo latinično i prerađeno izdanje Parčićeva misala iz 1927. donosimo samo kako bismo odmjerili postojeće stanje. U tom Misalu ne bilježe se jerovi u slabom položaju, a slovo $a$ je na mjestu jerova u jakom položaju zabilježeno kao rezultat vokalizacije karakteristične za hrvatski crkvenoslavenski jezik. Na temelju Vajsova izdanja dobivamo podatke o izgovornoj normi hrvatskoga novocsl. jezika u 19. st. i o njezinu variranju u odnosu na podatke iz Maloga azbukvara (1894.).

\section{Parčić (1860.) Parčić (1893.) $\quad$ Karaman (1741.) $\quad$ Vajs (1927.)}

Otıvêĉaetí (Par. 5) Otvêĉaets (Par. 78b) Otvê‘ĉajetı (Kar. LXXVb) Otvěćajet (Vajs 91a)

17 Uzimaju se primjeri koji su karakteristične potvrde istočnoslavenizirane vokalizacije, za razliku od onih koji su potvrđeni i u kanonskim spomenicima: šed-, togda.

18 Primjeri: svêtı (Par. 1, ocsl. svêtı, ali svêtí na Par. 1) : svêtı (Par. 78a) : svềtı (Kar. LXXVb): svêt (Vajs 90a), kıtebê (Par. 1, ocsl. kb, združeno pisanje prednaglasnice, nedosljedno) : kb tebê (Par. 78a) : $k$ tebě (Vajs 90a), plttí (Par. 1, ocsl. plstb) : plbtb (Par. 78a) : plt (Vajs 90a/813), díni (Par. 4, ocsl. dbnb) : denb (Par. 78b) : dan (Vajs 93b), hoĉetí bitit (Par. 4) : hoĉetb biti (Par. 78b) : hoćet biti (Vajs 93a), sl estestvomí (Par. 5, ocsl. I jd. sb estbstvomb, vokalizacija u slabom položaju!, istočnoslavenizacija) : Sb estestvomb (Par. 78b) : Si estestvom (Kar. LXXVb) : Sjestestvom (Vajs 93b). 
Također, uočava se veća koncentracija nezabilježene vokalizacije jakih jerova u Misi iz 1860. negoli u Misalu (1893.):

\begin{tabular}{|llll|}
\hline Parčić (1860.) & Parčić (1893.) & Karaman (1741.) & Vajs (1927.) \\
\hline v1 díní (Par. 4) & vb denь (Par. 79a) & V1 denı (Kar. LXXVIa) & v dan (Vajs 91a) \\
\hline
\end{tabular}

Ukoliko se slovima za ,pune vokale“ i bilježi vokalizacija nekadašnjih jerova u jakom položaju, slovo $a$ (karakteristika hrvatskoga crkvenoslavenskog jezika) daleko je češće u izdanju Mise 1860. negoli u Misalu (1893.). Glede bilježenja vokalizacije jakih jerova, svjedočimo značajnijemu utjecaju istočnoslaveniziranih izdanja ( $e$ ili $o$ ), a po čuvanju štapića, kao znaka za nevokalizirani jaki jer, svjedočimo obnavljanju ocsl. norme:

\begin{tabular}{|llll|}
\hline Parčić (1860.) & Parčić (1893.) & $\begin{array}{l}\text { Karaman } \\
\text { (1741.) }\end{array}$ & Vajs (1927.) \\
\hline sadrıžití se (Par. 5) & sbdrıžitb se (Par. 78b) & $\begin{array}{l}\text { soderžit sê’ } \\
\text { (Kar. LXXVb) }\end{array}$ & sdržit se (Vajs 91a) \\
\hline Sa ovíca-mi (Par. 7) & sь ovbcami (Par. 79b) & $\begin{array}{l}\text { so ovcami (Kar. } \\
\text { LXXVIa) }\end{array}$ & s ovcami (Vajs 91b) \\
\hline Konací (Par. 7) & konecь (Par. 79a) & $\begin{array}{l}\text { konecc (Kar. } \\
\text { LXXVIa) }\end{array}$ & konac (Vajs 91b) \\
\hline
\end{tabular}

Osobito je zanimljivo uočiti kako se u Misi za umrle iz Parčićeva misala (1893.) pojavljuje i apostrof kao znak za slabi jer na kraju riječi, što dosada nismo mogli pronaći u radovima koji su se bavili istraživanjem jezika Parčićeva misala, i to samo u riječi blag' (dvije potvrde): «而市'(Par. 79a).

\begin{tabular}{|llll|}
\hline Parčić (1860.) & Parčić (1893.) & Karaman (1741.) & Vajs (1927.) \\
\hline blag1 (Par. 6) & blag' (Par. 79a) & blag1 (Kar. LXXVIa) & blag (Vajs 91b) \\
\hline
\end{tabular}

Slova kojima se bilježi vokalizacija jera u Misi za umrle iz Misala (1893.) tanja su i manja od ostalih, npr.

\begin{tabular}{|c|c|}
\hline 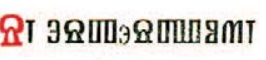 & (Par. 78b) \\
\hline घпт ФьэР & (Par. 79a) \\
\hline
\end{tabular}




\begin{tabular}{|c|c|c|}
\hline & Misa (1860.) & Misal (1893.) \\
\hline 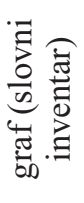 & $\begin{array}{l}\text { I (ъ) i Í (ь): uzor u } \\
\text { Karamanovim izdanjima }\end{array}$ & $\begin{array}{l}\text { I (ne razlikuju se jor i jer) i ' }(2 \mathrm{x}) \text { : uzor u hrvat- } \\
\text { skoglagoljskim spomenicima, ali stanje ne ko- } \\
\text { respondira samo s početkom redakcijskih formi- } \\
\text { ranja }^{19} \text { (od } 13 \text {. st.), kada je standardiziran štapić, } \\
\text { odnosno druga generacija apostrofa }\end{array}$ \\
\hline 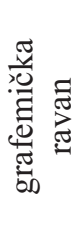 & $\begin{array}{l}\text { tradicija bilježenja slabih } \\
\text { jerova prema „,nepokv } \\
\text { arenim“"istočnoslaven } \\
\text { iziranim slovnicama u } \\
\text { odnosu na ocsl. normu } \\
\text { (pretpostavljena mjesta) }\end{array}$ & $\begin{array}{l}\text { Vajsov misal svjedoči da se izgovor slabih jerova } \\
\text { nije pretpostavljao, a tradicija je bilježenja } \\
\text { u odnosu na ocsl. normu - nema ispuštanja! } \\
\text { (istočna novocsl. izdanja kao sigurnosni } \\
\text { predložak) }\end{array}$ \\
\hline
\end{tabular}

Tablica 2. Bilježenje jerova u slabom položaju

Vanda Babič, kao i glavnina hrvatskih paleoslavista i paleokroatista, ističe kako se upravo Dragutin A. Parčić vratio hrvatskoj redakciji, i to zapisivanjem štapića za jerove u Misalu (1893.), ali je za razliku od Misala (1483.) njegova uporaba dosljedna: čuva slova za jerove u nekadašnjem slabom položaju. ${ }^{20} \mathrm{Na}$ razini slovnoga inventara (grafetička narav, osobito ako se u obzir uzme pisarska tradicija u odnosu na slabe jerove) poslužio se rješenjima hcsl. norme 13. stoljeća (+ apostrof kao korektiv), ali na razini distribucije po položajima (što je u odnosu na pisarsku tradiciju za slabe jerove grafetička, a u odnosu na izgovornu vrijednost jakih jerova grafematička ravan) riječ je o poštivanju ocsl. norme.

\begin{tabular}{|c|c|c|}
\hline & Misa (1860.) & Misal (1893.) \\
\hline \multirow{2}{*}{ 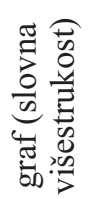 } & I (ъ) i I I (ь) & I (ne razlikuju se jor i jer) \\
\hline & $a$ & $e, o$ (niže i tanje otisnuta slova) \\
\hline
\end{tabular}

19 Štapić je jedini znak za jerove u Parčićevu misalu (apostrof se potvrđuje svega dva puta na kraju riječi blag 'za označavanje slabe pozicije, a prema Mihaljeviću (2009) takva je tradicija do sredine 14. stoljeća. Da se vraćao samome početku redakcijskih formiranja, u obzir bismo morali uzeti i slovo za jor u obliku ključa, ali činjenica da Misal ipak potvrđuje i štapić i apostrof ukazuje na stanje u spomenicima već od kraja 12. stoljeća. S obzirom na to da se isti znak pojavljuje u riječi 'zgubiši (Par. 79a), prema zgubiši (Par. 6), ne zgubiši (Kar. LXXVIa) i zgubiši (Vajs 91b), držimo da apostrof ima korekturnu ulogu i da je u vezi s propustima (u tiskanju) (usp. ŽAGAR 2007). Valja napomenuti i to da Parčić već u misi Vb prazd'nikb Neporočnago Začetiê bl. Marie Dêvy (litografija, Krk 1864.) nekadašnju slabu poziciju jera bilježi apostrofom. 


\begin{tabular}{|c|c|c|}
\hline \multirow{2}{*}{ 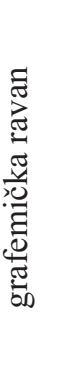 } & $\begin{array}{l}\text { ocsl. tradicija bilježenja jakih } \\
\text { jerova (i jor i jer), uzor su kanonski } \\
\text { spomenici, a ne Karaman; jak } \\
\text { položaj, razlikuju se tvrdi i } \\
\text { meki jerovi; Karaman je bilježio } \\
\text { vokalizaciju jakih jerova! }\end{array}$ & $\begin{array}{l}\text { osobitost hrvatskoglagoljskih } \\
\text { spomenika u 14. i 15. st. (npr. Vat. } \\
\text { Illir. 4, Prvotisak) bilježenje je } \\
\text { nevokaliziranih jakih jerova }\end{array}$ \\
\hline & $\begin{array}{l}\text { hrvatska redakcija od 13. stoljeća } \\
\text { bilježi vokalizaciju slovom za puni } \\
\text { vokal } a\end{array}$ & $\begin{array}{l}\text { Ocsl. praksa, rješenja kodificirana } \\
\text { u istočnim novocsl. normativnim } \\
\text { priručnicima }\end{array}$ \\
\hline
\end{tabular}

Tablica 3. Jerovi u nekadašnjem jakom položaju

Inventar kojim u Misi (1860.) Parčić bilježi jake jerove oblikovan je po uzoru na Karamana (slovni inventar: štapić $i$ štapić s dijakritičkim znakom), ali je praksa bilježenja tvrdih i mekih jerova na pretpostavljenim mjestima kod Parčića povratak ocsl. izvorima, osobito ako se u obzir uzme činjenica da bilježi i nevokalizirane jake jerove. Kada pak bilježi vokalizaciju, ona je prema hosl. spomenicima od 13. stoljeća. U Misalu 1893. bilježi jake jerove štapićem (hcsl. pisarska tradicija od 13. stoljeća), ali Vajs svjedoči da se izgovor pretpostavlja (u njegovu izdanju potvrđeno slovom $a$ ). Kada pak bilježi vokalizaciju u Misalu, to čini prema istočnim novocsl. uzorima (slova $e, o$ ).

Već kod pisanja jerova u Misi (1860.) i Misalu (1893.) možemo posvjedočiti prirodi procesa jezičnoga obnavljanja - rješenja se preuzimaju prema ocsl. kanonskim spomenicima, istočnim novocsl. izdanjima i hcsl. spomenicima (ovisno o rješenju, potvrđuje se kontinuitet od 12. do 15. stoljeća).

\section{Jeri}

Parčić u litografskom izdanju Mise za mrtve (1860.) poziciju jerija bilježi slovima $i i$ (štapić + dvadesetično $i)^{21}$, za razliku od Levakovića (1648.) i Karamana (1741., 1791.), kod kojih se slovom $\bar{\imath}$ bilježi jeri. To, dakako, nije u skladu s tradicijom hrvatskoglagoljskih spomenika i normom hcsl. jezika jer jedna od prvih promjena koja određuje taj jezik jest promjena jerija $\mathrm{u} / \mathrm{i} /, \mathrm{i}$ to do početka 12 . stoljeća. ${ }^{22}$

Možemo se zapitati ima li Parčićevo slovno rješenje veze s istočnim novocsl. izdanjima (Levaković, Karaman), kada je očigledno izmijenjeno? Činjenica je da

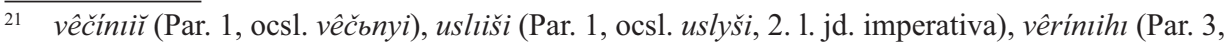
ocsl. vêrbnyihı, nedostaje $i$ u gram. morfu), (otı vísêkoe) uzii (Par. 3, ocsl. G jd. uz/d/y), imatí priiti (Par. 4), divíniiu (Par. 4, ocsl. divbnyi), mirtvii (Par. 4), uličeniimı (Par. 7). Već u misi Vb prazd'nikb Neporočnnago Začetiê bl. Marie Dêvy (litografija, Krk 1864.) Parčić nekadašnju slabu poziciju jera bilježi apostrofom, a umjesto slova bi za jeri, bilježi, poput Karamana, slovo $i$ s ravnom crticom.

22 DAMJANOVIĆ 2008: 11; MIHALJEVIĆ 2009: 294. 
Parčić rabi digrafski način bilježenja jerija, nastavljajući se na ocsl. glagoljičnu (i ćiriličnu) pismovnu tradiciju, ali i na prve hcsl. spomenike (Bečki listići bilježe apostrof $+i$ na trima mjestima, ali s fonematskom vrijednošću $/ \mathrm{i} /)^{23}$, a ne na tradiciju istočnoslavenske crkvene redakcije, koja je usustavljena dvjema gramatikama Zizanija i Smotrickoga te potvrđena u istočnim novocsl. izdanjima kao $\bar{l}$.

U Parčićevu misalu (1893.) slovom $i$ dosljedno je zabilježena promjena jerija $\mathrm{u} i$, koja karakterizira hrvatski crkvenoslavenski jezik.

\begin{tabular}{|c|c|c|}
\hline \multicolumn{2}{|r|}{ Misa (1860.) } & Misal (1893.) \\
\hline 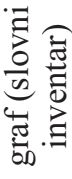 & $\begin{array}{l}\text { li }(\text { štapić }+ \text { dvadesetično } i) \\
\text { različito od Karamanova misala }(\vec{l})\end{array}$ & $i$ \\
\hline 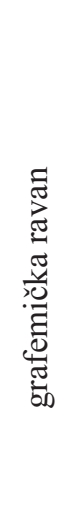 & $\begin{array}{l}\text { istočni novocsl. spomenici kao sigurnosni } \\
\text { predložak: tradicija bilježenja ocsl. jerija } \\
\text { zadržala se (u određenim pozicijama, } \\
\text { različito u odnosu na jezik i pismo) u } \\
\text { istočnoslavenskim jezicima, ali i u dvjema } \\
\text { slovnicama koje propisuju istočni novocsl. } \\
\text { jezik } \\
\text { Parčić je odabrao drugačiji način } \\
\text { pisanja (digrafski) kako bi štapićem uz } \\
\text { dvadesetično } i \text { ukazao na fonematsku } \\
\text { vrijednost /i/ i neutralizaciju /y/ > / i/ (hcsl. } \\
\text { 12. st.) }\end{array}$ & \multirow[t]{2}{*}{$\begin{array}{l}\text { bilježenje zamjene /y/ > /i/ u } \\
\text { hcsl. jeziku (jezik liturgijskih } \\
\text { spomenika), ali i u svim } \\
\text { južnoslavenskim jezicima (i } \\
\text { pismima) }\end{array}$} \\
\hline & usp. FgVind: ‘ + $i \mathrm{za} / \mathrm{i} /$ & \\
\hline
\end{tabular}

Tablica 4. Bilježenje jerija

Zaključuje se kako Parčić iznova promišljeno spaja ocsl. normu, istočnoslavenska rješenja i hrvatskoredakcijske osobitosti. Najprije mu je važno da se slovom obilježi pozicija nekadašnjega ocsl. jerija, i to digrafom/dvoslovom (dakle, drugačije u odnosu na istočnosl. rješenje) - što prema staroslavenskoj glagoljskoj pisarskoj normi (premda je ondje uobičajeno desetično $i$ uz jor), što, još vjerojatnije, kako bi ukazao na fonematsku vrijednost /i/ i početnu hosl. praksu

23 Slovo jeri zabilježeno je još samo u trima fragmentima najstarijega razdoblja (Budimpeštanski odlomci, Prva stranica Kijevskih listića, Grškovićev odlomak apostola). U kasnijim tekstovima digraf, koji se sastoji od znaka za jer (štapića ili apostrofa) i dvadesetičnoga $i$, pojavljuje se povremeno i u većini slučajeva označava skupinu /ji/, tj. štapić ili apostrof služe za označivanje jotacije (MIHALJEVIĆ 2009: 294). 
(kombinacija štapić + dvadesetično $i$ podsjeća, primjerice, na Bečke listiće, gdje je ' + dvadesetično $i$ oznakaza vrijednost /i/).

3. Jat

U Misi 1860. i Misalu 1893. jat je nezamijenjen (slovima za samoglasnike/e/ ili /i/). Inače, hrvatski crkvenoslavenski glasovni sustav sve do 14. i 15. stoljeća poznaje jat (s posebnom fonemskom vrijednošću) ${ }^{24}$, a i slovo je postojano $\mathrm{u}$ hrvatskoglagoljskim liturgijskim knjigama. ${ }^{25}$ Nadalje, prihvaća se stav Vande Babič o jatu u Parčićevu misalu kao staroslavenskomu jatu ${ }^{26}$, ali je isto tako i hrvatski crkvenoslavenski (do 14./15. stoljeća). Podsjećamo da nije crkvenoslavenizam sve što je odraz starine, već sve što je dio sustava, dio strukture; u tom smislu jat može biti i obilježje hrvatskoga crkvenoslavenskog jezika.

\begin{tabular}{|c|c|c|}
\hline \multicolumn{2}{|r|}{ Misa (1860.) } & Misal (1893.) \\
\hline 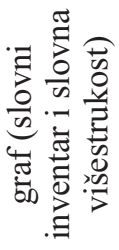 & $\begin{array}{l}\hat{e} \text { s točkicom } / \mathrm{je} / \\
\hat{e} \text { bez točkice } / \mathrm{ja} /{ }^{27} \\
\text { uzor: Karaman }\end{array}$ & $\hat{e} / \mathrm{je} /, / \mathrm{ja} /$ \\
\hline \multirow{3}{*}{ 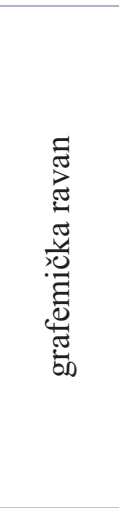 } & $\begin{array}{l}\text { bilježi se ocsl. i hcsl. jat, a ne istočni } \\
\text { novocsl. jat (izgovorna norma) }\end{array}$ & $\begin{array}{l}\text { ocsl. i hcsl. jat (12. i 13. stoljeće: } \\
\text { u većini tekstova slovo jat na } \\
\text { položaju psl. jata pojavljuje se } \\
\text { znatno češće od slova } e \text { i } i^{28}\end{array}$ \\
\hline & $\begin{array}{l}\text { samo jedna pogreška prema istočnosl. } \\
\text { uzorima: } m e \hat{e}(* m e ̨>\text { istočni novocsl. } \\
m j a>\text { hcsl. me) (Par. 7) }\end{array}$ & $\begin{array}{l}\text { nekoliko primjera bilježenja } \\
\text { prednjega nazala proširenoga } \\
\text { protezom prema hrvatskoj } \\
\text { redakciji (početak hcsl. jezika!): }{ }^{29} \\
\text { êsti (ali i oblik jesti od *jęsti) }\end{array}$ \\
\hline & $\begin{array}{l}\text { jatom se bilježi umekšanost suglasnika } \\
/ 1 \text { \%/,/n'/,/r'/: zemlê /zemlja/ }\end{array}$ & $\begin{array}{l}\text { jatom se ne bilježi umekšanost } \\
\text { suglasnika /1\%/,/n\%,/r'/: zemla }\end{array}$ \\
\hline
\end{tabular}

Tablica 5. Bilježenje jata

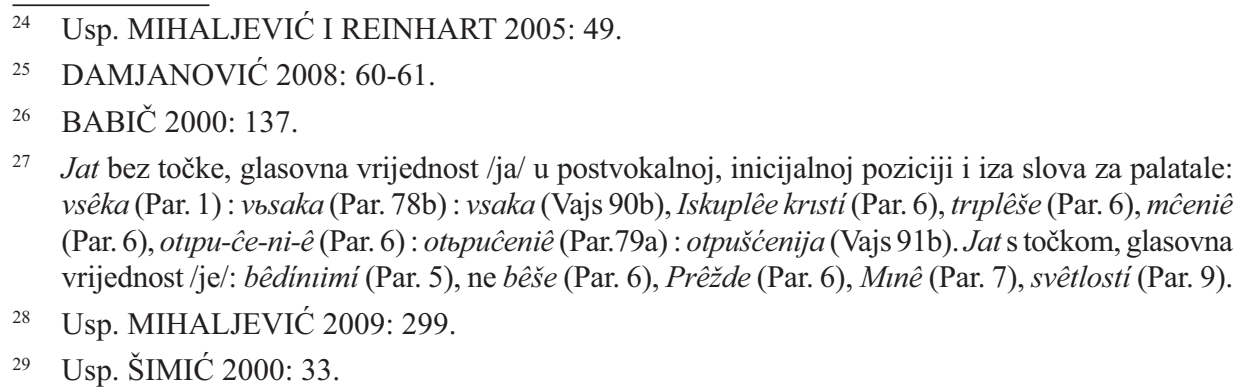


Prema bilježenju jata, zaključuje se da Parčićeva jezična koncepcija počiva na istim načelima 1860. i 1893., ali su rješenja različita. Ta se načela mogu izraziti rečenicom: važno je osigurati razumljivost i podsjetiti na poznato, ali da se ne iznevjere ocsl. norma i hcsl. rješenja.

U Misi (1860.) Parčić želi zadržati jat $\mathrm{s}$ točkicom i bez točkice prema istočnim novocsl. uzorima jer su ustaljeni, jer vjerno odražavaju ocsl. izgovornu normu i jer je proces obnove tek započeo, ali ne u svim pozicijama. U skladu s normom hcsl. jezika, Parčić u Misi slovom jat (bez točkice) više ne bilježi refleks prednjega nazala, kao što je to slučaj s Karamanovim izdanjima. Samo je jednom pogriješio, u primjeru mê (Par. 7), što potvrđuje našu pretpostavku da je Karamanova izdanja imao pred sobom kao sigurnosni predložak. U Misalu (1893.) je Parčić želio dokraja raščistiti razinu pisma, pa uvodi jedinstveno slovo jat, bez nadrednih znakova za distinkciju /je/ i /ja/ (prema ocsl. normi, ali i početnoj hcsl. normi).

\section{Bilježenje suglasnika /l'/,/n'/,/r'/}

Već u Levakovićevu Brevijaru (1648.) palatalnost suglasnika /1/ i /n/ označava se dijakritičkim znakom ', ali i slovom jat te prejotiranim ju. Kod oblika lične zamjenice za 3. osobu, koji dolaze s prefiksom $n$ - zbog prijedložne veze, ta umekšanost nije označena. U Brevijaru je i umekšanost /r'/ dvaput označena slovima jat i ju $u^{30}$. Karaman (1741., 1791.) označava njihovu mekoću apostrofom ponad slova $l, n, r$, potom jerom (í) te slovima jat i $j u$.

Parčić 1860. bilježi umekšane /1/, /n/, /r/ dijakritičkim znakom (apostrofom ponad slova), slovom jat, jer i slovom ju: Carju (Par. 5, 8), Suditelju (Par. 6), Iskuplêe kristí (Par. 6), Agníče.

Kod oblika lične zamjenice s predmetkom $n$ - u Misi 1860. bilježimo dvostrukosti: bilježenje $v \imath$ ně̆-že (Par. 5, prema ocsl. normi i hcsl. spomenicima te u Levakovića: lična i odnosna zamjenica s $n$ - za 3. lice bez znaka za umekšanje), ali i o n'emiže (Par. 5, s dijakritičkim znakom).

\begin{tabular}{|lll|}
\hline & Misa (1860.) & Misal (1893.) \\
\hline & & \\
& $l, n, r+$ dijakritički znak ، & - \\
& $l, n, r+$ meki jer $(i=b)$ & - \\
& slovo jat & - \\
& slovo ju & slovo ju \\
\hline
\end{tabular}

$\overline{30}$ BABIČ 2000: 92. 


\begin{tabular}{|c|c|c|}
\hline 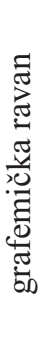 & 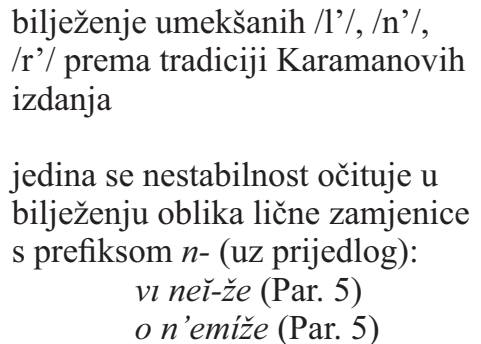 & $\begin{array}{l}\text { umekšani /l'/, /n'/,/r'/ bilježe } \\
\text { se samo s pomoću slova ju: } \\
\text { slzdatelju (Par. 78a), glagolju } \\
\text { (Par. 79b) } \\
\text { (tradicija hrvatskoglagoljskih } \\
\text { spomenika 15. i 16. st. ) }\end{array}$ \\
\hline
\end{tabular}

Tablica 6. Bilježenje suglasnika /l'/,/n'/,/r'/

\section{Slovo šta i šta s nadrednim točkicama}

Slovo šta do 15. je stoljeća u hrvatskoglagoljskim tekstovima označavalo /ć/, /šć/ $\mathrm{i} /$ št $/{ }^{32}$ Od 15 . stoljeća nadalje glagoljaši skupinu/šć/ bilježe i kombinacijom $\check{s}+\hat{c}$ jer dodatno žele upozoriti da nije riječ o glasu/ć/. Između tih dvaju slova znaju stoga staviti i apostrof $\breve{s} \hat{c}$. No, u liturgijskim tekstovima pisanje je šta s pomoću dvaju znakova $(\breve{s}+\hat{c}$ ili $\check{s}+t)$ rijetkost. ${ }^{33}$ To znači da je Parčić u Misi i Misalu preuzeo, u ovom bi slučaju opravdano bilo istaknuti i ,nastavio“, tradiciju hrvatskoglagoljskih liturgijskih tekstova, koji tradicionalno slovom šta bilježe /ć/ i /šć/. U istočnoslavenskim spomenicima, prema normativnim gramatikama, zabilježeni su refleksi /ć/ i/šć/, a drugi se $u$ istočnim novocsl. spomenicima donosi s dvjema nadrednim točkicama.

\begin{tabular}{|lll|}
\hline & Misa (1860.) & Misal (1893.) \\
\hline & & \\
\hline & slovo šta \\
\hline & \\
\hline \\
\hline
\end{tabular}

Tablica 7. Slovo šta

\footnotetext{
31 Usp. VINCE 1981: 15-21.

32 DAMJANOVIĆ 2008: 59.

33 MIHALJEVIĆ 1992: 12; ŠIMIĆ 2000: 41; JURČEVIĆ 2002: 92.

34 U Parčićevu izdanju Mise (1860.) slovo šta (bez točkica) označuje i /ć/ i /šć/: pomagajuĉeju (Par. 3), otı miĉeniê (Par. 3), hoĉetí (Par. 4), otıvêĉatí (Par. 5), Truždenı iĉeme (Par. 6), Moleĉumu (Par. 6), greducîu (Par. 12).
} 


\section{Slovo Zêlo}

Dok je Levaković danim slovom u Misalu (1631.) i Brevijaru (1648.) označavao samo brojevnu vrijednost osam, Karaman je to slovo pod utjecajem istočnoslaveniziranih gramatika Zizanija i Smotrickoga rabio i u zapisivanju pojedinih riječi: Zllo, Zlloba i sl.

Već je u starockrvenoslavenskim tekstovima afrikata /3/ bila zamijenjena slovom za frikativ /z/. U hrvatskom se crkvenoslavenskom jeziku, prema tome, slovo Zêlo pojavljuje samo kao znak za broj osam, a od druge polovine 14. stoljeća i kao tzv. alfabetska suspenzija za riječ Zêlo. Jedino u Grškovićevu odlomku apostola

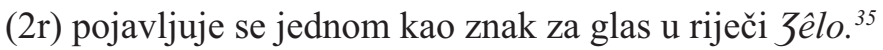

Nestabilnost u Misi (1860.) svjedoči da je riječ o glasovnoj vrijednosti /z/ i spremnosti za prevladavanje grafijskoga uzora u istočnom novocsl. izdanju ${ }^{36}$.

\begin{tabular}{|c|c|c|}
\hline \multicolumn{2}{|r|}{ Misa (1860.) } & Misal (1893.) \\
\hline 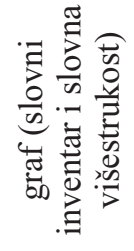 & slovo $z$ (zemli) & slovo $z$ (zemli) \\
\hline 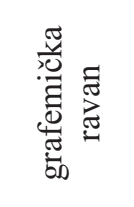 & $\begin{array}{l}\text { nestabilnost u održavanju istočne } \\
\text { novocsl. pisarske prakse (Karaman: } \\
\text { 3ılo, Zlloba, ali fonematska vrijednost } \\
\text { /z/): } \\
\text { Zílosti (Par. 6) ali i zlosti (Par. 5) }\end{array}$ & $\begin{array}{l}\text { bilježenje hcsl. zamjene /3/ } \\
>\text { /z/ (proces započeo već u } \\
\text { ocsl. tekstovima) }\end{array}$ \\
\hline
\end{tabular}

Tablica 8. Slovo Zêlo

\section{Zaključak}

Parčićeva domisalska izdanja (primjer Mise 1860.) na razini grafemičke analize potvrđuju (Berčićevu) nasljedovanu uređivačku i „obnoviteljsku“ koncepciju liturgijskih knjiga. Koncepcija je to koja se čak 30 godina prije izdanja Misala ovjerava izvornom i Parčiću prepoznatljivom, jedino što se konkretna rješenja razlikuju. Ta različita rješenja u Misi (1860., ali i 1864.) i Misalu (1893.) osnažuju,

\footnotetext{
35 MIHALJEVIĆ 2009: 295.

36 Misa (1860): Zlla (Par. 3), Zilosti (Par. 6) : zlosti (Par. 79a) : Zlosti (Kar. LXXVIa) : zlosti (Vajs 91b), ali u Misi (1860.) i: prostivi zlosti (Par. 5).
} 
premda na drugačiji način (grafetička i grafemička razina, odnosno razina slovopisne/pravopisne i fonološke norme), istu prirodu Parčićeve jezične koncepcije.

Ova kratka analiza potvrđuje da su njegovi uzori u odabirima bili općecrkvenoslavenski, hrvatski crkvenoslavenski (u kontinuitetu od 12. do 16. stoljeća) i istočni novocrkvenoslavenski (ne samo zbog sravnjivanja s Vulgatom). Ipak, Parčić već u Misi potvrđuje da ne slijedi vjerno istočne novocsl. grafijske uzore, nego vlastitim autorskim doprinosom pokušava u ravnotežu dovesti obilježja različitih crkvenoslavenskih tradicija, dakako, vodeći se hcsl. tradicijom. Sve je već na slovnoj razini, dade se zaključiti, u skladu s jezičnopolitičkim odrednicama i zadacima Cyrillomethodiane: opremiti i otisnuti nove crkvenoslavenske liturgijske knjige nacionalnoga (hrvatskog) i nadnacionalnoga (sveslavenskog) značenja. ${ }^{37}$

\section{Bibliografija}

\section{Kratice}

hcsl. hrvatski crkvenoslavenski jezik (od 12. do 16. stoljeća)

novocrkvenoslavenski jezik javlja se u određenoj sredini usporedno

novocsl. s književnim jezikom kojemu je osnovica narodni, domaći idiom (nacionalni književni jezik)

hrvatski hrvatski novocrkvenoslavenski jezik hrvatskih liturgijskih knjiga u 19. i novocsl. 20. stoljeću

istočni istočni novocrkvenoslavenski jezik inačica je novocrkvenoslavenskoga

novocsl. jezika, a javlja se u hrvatskim liturgijskim knjigama 17. i 18. stoljeća

ocsl. opće(crkveno)slavenski književni jezik (jezik kanonskih tekstova 10. i 11. stoljeća)

Kratice izvora

FgVind $\quad=\quad$ Stoljeća Beč Ösmenta Vindobonensia), kraj 11. i poč. 12. stoljeća, Beč: Österreichische Nationalbibliothek (sign. Cod. Slav. 136).

37 Misa (1860.) pokazuje zanimljivosti (uglavnom konzervativnost) i na drugim jezičnim razinama. Spomenut ćemo: (ne)provođenje glasovnih promjena (razsuditi Par. 4 : rasuditi Par. 78b), očuvanost $i$-promjene ( $\mathrm{G}$ jd. ženskoga roda sımrıti), zabilježenu kategoriju instrumental apsolutni (prijevod latinskoga ablativa apsolutnog, karakterističan za hesl. tekstove, GADŽIJEVA i dr. 2014: 337): I blagodatiju tvoeju imı pomagajuceju (Par. 1, Par. 78b, Vajs 91a, usp. i blagodatïu tvoeju imı pomogajuceju (Kar. LXXVb), genitiv, kasnije dativ po rekciji (uz glagole koji označuju bježanje, GADŽIJEVA i dr. 2014: 325): ubêžati suda (Par. 1) : ubêžati sudu (Par. 78b) : ubê žati suda (Kar. LXXXVb) : uběžati sudu (Vajs 91a), očuvanu deklinacijsku posebnost (kratki/dugi oblici) participa (u predikatnoj i determinativnoj ulozi, npr. u atributnoj službi): greduĉiŭ gnêvı itd. (usp. SUDEC 2008: 517; GADŽIJEVA i dr. 2014) i dr. 


\begin{tabular}{|c|c|c|}
\hline Par. (78a-84b) & $=$ & $\begin{array}{l}\text { Rimbski Misalb slavênbskimb ezikomb presv. G. N. Urbana } \\
\text { Papi VIII povelêniemb izdanb - Missale Romanum slavonico } \\
\text { idiomate ex decreto sacrosancti Concilii Tridentini (Rim: } \\
\text { Congr. de Propaganda Fide, }{ }^{1} 1893 \text { ) ili Parčićev misal }\end{array}$ \\
\hline Par. (1-12) & $=$ & $\begin{array}{l}\text { Misi za umr'šee s koralnim napjevom (litografija, Galevac } \\
\text { 1860), Zagreb: Arhiv Provincijalata franjevaca trećoredaca } \\
\text { na Ksaveru, sig. XIX. a. } 58\end{array}$ \\
\hline $\begin{array}{l}\text { Kar. (LXXVa- } \\
\text { LXXXIb) }\end{array}$ & $=$ & $\begin{array}{l}\text { Missalb rimskîj slavenskimb êzykomb - Missale romanum } \\
\text { slavonico idiomate (Rim, Congr. de Propaganda Fide, 1741) } \\
\text { ili Karamanov misal }\end{array}$ \\
\hline Vajs (90a-96b) & $=$ & $\begin{array}{l}\text { Rimski misal slověnskim jezikom prěsv. G. N. Urbana } \\
\text { Papi VIII povelěnjem izdan - Missale Romanum slavonico } \\
\text { idiomate ex decreto sacrosancti Concilii Tridentini (Rim: } \\
\text { Congr. de Propaganda Fide, 1927) ili Vajsov misal }\end{array}$ \\
\hline
\end{tabular}

Izvori

KARAMAN, Mateo (prir.). 1741. Missalb rimskij slavenskimbêzykomb Missale romanum slavonico idiomate. Rim: Congr. de Propaganda Fide, Ex typographia polyglotta (Zagreb: Nacionalna i sveučilišna knjižnica, Zbirka rukopisa i starih knjiga, sign. 37 RIIA-4으.

PARČIĆ, Dragutin Antun (prir.). 1860. Misi za umr'šee s koralnim napjevom (litografija). Galevac (Zagreb: Arhiv Provincijalata franjevaca trećoredaca na Ksaveru, sign. XIX. a. 58, 1-12).

PARČIĆ, Dragutin Antun (prir.). 1893. Rimbski Misalb slavênbskimb ezikomb prêsv. G. $N$. Urbana Papi VIII povelêniemb izdanb Missale romanum slavonico idiomate ex decreto sacrosancti Concilii Tridentini. Rim: Congr. de Propaganda Fide, Ex typographia polyglotta (Pretisak 2011. Podgorica: NVO „Ivan Mažuranić“‘, Fond za manjine Crne Gore).

VAJS, Josip (prir.). 1927. Rimski misal slověnskim jezikom prěsv. G. N. Urbana Papi VIII povelénjem izdan - Missale Romanum slavonico idiomate exdecreto sacrosancti Concilii Tridentini. Rim: Congr. de Propaganda Fide, Ex typographia polyglotta. https:// dl.dropboxusercontent.com/u/50743485/Misali\%20i\%20obrednici/OBRADJENstaroslavenski_misal1927.pdf(posjet 9. 8.2015).

\section{Literatura}

BABIČ, Vanda. 2000. Vpliv vzhodne cerkvene slovanščine na hrvaške glagolske tekste v 17. in 18. stoletju. Ljubljana: Razprave Filozofske fakultete.

BADURINA, Anđelko. 1993. Nepoznati Parčić. U Zbornik radova sa znanstvenoga skupa Život i djelo Dragutina A. Parčića (Zadar-Preko 18. i 19. listopada 1992), ur. Julije Derossi, 155-182. Zadar: Matica hrvatska - Ogranak Zadar. 
BOLONIĆ, Mihovil. 1973. O životu i radu Dragutina A. Parčića (U povodu 70. obljetnice smrti). Bogoslovska smotra 2: 418-438.

BONEFAČIĆ, Kvirin Klement (Daroslav). 1903. Dragutin A. Parčić 26. V. 1832. - 25. VII. 1902. Krk: Kurykta.

DAMJANOVIĆ, Stjepan. 2005. Staroslavenski jezik. Zagreb: Hrvatska sveučilišna naklada.

DAMJANOVIĆ, Stjepan. 2008. Jezik hrvatskih glagoljaša. Zagreb: Matica hrvatska.

GADŽIJEVA, Sofija, Ana KOVAČEVIĆ, Milan MIHALJEVIĆ, Sandra POŽAR, Johannes REINHART, Marinka ŠIMIĆ, Jasna VINCE. 2014. Hrvatski crkvenoslavenski jezik. Prir. Milan Mihaljević. Zagreb: Hrvatska sveučilišna naklada, Staroslavenski institut.

HERCIGONJA, Eduard. 2004. Na temeljima hrvatske književne kulture. Filološkomedievističke rasprave [Hrvatska jezična baština, knj. 4]. Zagreb: Matica hrvatska.

JAGIĆ, Vatroslav. 1910. Erinnerungsblätter an Ivan Berčić und Dragutin Parčić. Archiv für slavische Philologie 31: 288-300.

JURČEVIĆ, Ivan. 2002. Jezik hrvatskoglagoljskih tiskanih brevijara. Osijek: Sveučilište Josipa Jurja Strossmayera, Pedagoški fakultet.

LUKIĆ, Milica. 2012. Dragutin Antun Parčić i njegov Rimski misal slavenskim jezikom (Rim, 1893.) - (u povodu 100. obljetnice Parčićeve smrti i pretiska njegova glagoljskog Misala u Crnoj Gori). Lingua Montenegrina 10: 317-337.

LUKIĆ, Milica, Vera BLAŽEVIĆ KREZIĆ. 2014. Cyrillomethodiana oživljena ili O Strossmayerovu projektu obnove ćirilometodske baštine. U Divanimo, dakle postojimo. Književnojezične i jezičnopovijesne studije, ur. Josip Cvenić, 210-241. Osijek: Ogranak Matice hrvatske u Osijeku.

LUKIĆ, Milica, Marina PILJ TOMIĆ. 2010. Staroslavenske liturgijske knjige na hrvatskom nacionalnom prostoru u XIX. stoljeću. Lingua Montenegrina 3: 75-107.

MIHALJEVIĆ, Milan. 2009. Hrvatski crkvenoslavenski jezik. U Povijest hrvatskoga jezika - 1. knjiga: Srednji vijek, ur. Josip Bratulić i dr., 248-349. Zagreb: Croatica.

MIHALJEVIĆ, Milan, Johannes REINHART. 2005. The Croatian Redaction: Language and Literature. Incontri Linguistici 28: 31-82.

PETROVIĆ, Ivanka. 1979. Franjo Rački - otac hrvatske Cyrillo-Methodiane. Zbornik Zavoda za povijesne znanosti Istraživačkog centra Jugoslavenske akademije znanosti i umjetnosti 9: 47-99.

SUDEC, Sandra. 2008. Deklinacija aktivnoga participa prezenta u hrvatskome crkvenoslavenskome jeziku. Slovo 56-57: 517-529.

ŠIMIĆ, Marinka. 2000. Jezik Muke po Mateju u hrvatskoglagoljskim misalima. Slovo 50: 5-117.

TANDARIĆ, Josip Leonard. 1993. Hrvatska glagoljska liturgijska književnost-Rasprave i prinosi. Zagreb: Kršćanska sadašnjost.

VINCE, Jasna. 1981. Fonemi 1, n, j i njihova grafija u hrvatskoglagoljskim rukopisima. Slovo 31: 15-21.

ŽAGAR, Mateo. 2007. Grafolingvistika srednjovjekovnih tekstova. Zagreb: Matica hrvatska. 


\section{Croatian New Church Slavonic Language in the $19^{\text {th }}$ Century (Beginning of Linguistic Renewal in the Example of Dragutin Antun Parčić's First Editions)}

With regard to the so far clearly stressed and in the scholarly production ascertained characteristics of the language policy and the applied language practice in the restoration of liturgical books and Glagolitic tradition in the $19^{\text {th }}$ century the paper aims to determine the extent and quality of the contributions of D. A. Parčić in its shaping and realisation.

The proposed goal has been achieved through an analysis of the graphetic and graphemic specialities of the editions of Dragutin Antun Parčić (he also participated in the preparation of Chrestomathia linguae veteroslovenicae charactere glagolitico, Prag 1859, and Ulomci Sv. pisma, Prag 1864 -1871), known as his first independent editions before the Missal 1893 (e. g. Mrtvačka misa s koralnim napjevom 1860, Čin i Pravilo misi ošće že i molitvi prežde i po mise iz Rimskog misala 1881 etc.).

This paper concludes that internal analysis of the writing and the language (selected problems on graphetic and graphemic level) of the first Parčić's editions can verify certain principles of Parčić's linguistic conception. Therefore, this brief analysis confirms that (language) choices were influenced by Croatian Church Slavonic (continuously since $12^{\text {th }}$ to $16^{\text {th }}$ century) and East New Church Slavonic linguistic norm (not only due to reconciliation with the Vulgate).

It is the original and recognizable concept of Dragutin A. Parčić and it can be confirmed as many as 30 years before thereleaseof the Missal 1893. Within this linguistic conception only some concrete solutions had been varied (e. g. letter ,jer"), what we have shown in the graphetic and graphemic analysis. Different solutions in the Mass (1860, and 1864) and the Missal (1893) reinforce, although in a different way (orthographic and phonological norm), the same nature of Parčić's linguistic conception.

Keywords: Croatian Church Slavonic language, $19^{\text {th }}$ century, Dragutin A. Parčić, Mrtvačka misa s koralnim napjevom 1860, graphetic and graphemic specialities

Ključne riječi: hrvatski crkvenoslavenski jezik, 19. stoljeće, Dragutin A. Parčić, Mrtvačka misa s koralnim napjevom 1860., grafetičke i grafemičke posebnosti

Milica Lukić

Vera Blažević Krezić

Filozofski fakultet Sveučilišta J. J. Strossmayera u Osijeku HR-31000 Osijek, L. Jägera 9 mlukic@ffos.hr vblazevic1@ffos.hr 


\section{FILOZOFSKI FAKULTET SVEUČILIŠTA U ZAGREBU \\ ZAVOD ZA HRVATSKU POVIJEST \\ INSTITUTE OF CROATIAN HISTORY \\ INSTITUT FÜR KROATISCHE GESCHICHTE}
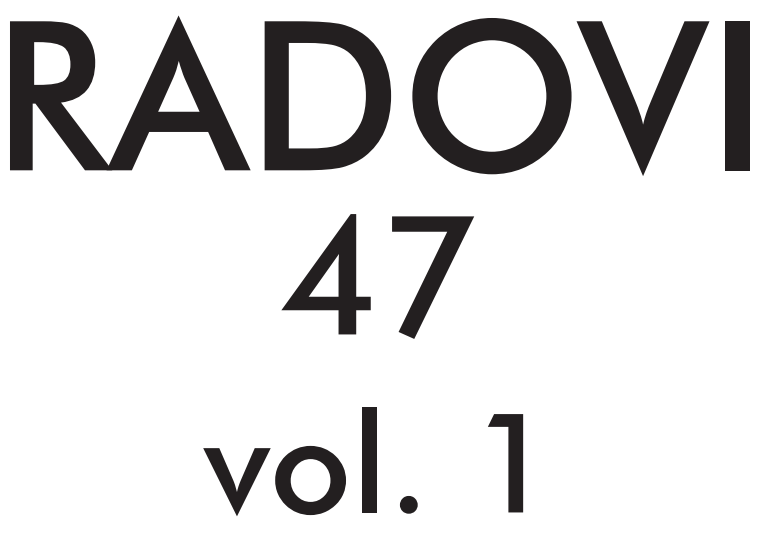

ZAVOD ZA HRVATSKU POVIJEST

FILOZOFSKOGA FAKULTETA SVEUČILIŠTA U ZAGREBU

\section{PF press \\ ZAGREB 2015.}




\title{
RADOVI ZAVODA ZA HRVATSKU POVIJEST FILOZOFSKOGA FAKULTETA SVEUČILIŠTA U ZAGREBU
}

\author{
Knjiga 47, vol. 1
}

\author{
Izdavač / Publisher \\ Zavod za hrvatsku povijest \\ Filozofskoga fakulteta Sveučilišta u Zagrebu \\ FF-press \\ Za izdavača / For Publisher \\ Vlatko Previšić \\ Glavni urednik / Editor-in-Chief \\ Hrvoje Gračanin \\ Izvršna urednica / Executive Editor \\ Inga Vilogorac Brčić \\ Uredništvo / Editorial Board
}

Bruna Kuntić-Makvić (stara povijest/ancient history), Zrinka Nikolić Jakus (srednji vijek/ medieval history), Hrvoje Petrić (rani novi vijek/early modern history), Željko Holjevac (moderna povijest/modern history), Tvrtko Jakovina (suvremena povijest/contemporary history),

Silvija Pisk (mikrohistorija i zavičajna povijest/microhistory and local history),

Zrinka Blažević (teorija i metodologija povijesti/theory and methodology of history)

Međunarodno uredničko vijeće / International Editorial Council

Denis Alimov (Sankt Peterburg), Živko Andrijašević (Nikšić), Csaba Békés (Budapest), Rajko Bratož (Ljubljana), Snježana Buzov (Columbus, Ohio), Svetlozar Eldarov (Sofija), Toni Filiposki (Skopje), Aleksandar Fotić (Beograd), Vladan Gavrilović (Novi Sad), Alojz Ivanišević (Wien),

Egidio Ivetić (Padova), Husnija Kamberović (Sarajevo), Karl Kaser (Graz),

Irina Ognyanova (Sofija), Géza Pálffy (Budapest), Ioan-Aurel Pop (Cluj),

Nade Proeva (Skopje), Alexios Savvides (Kalamata), Vlada Stanković (Beograd), Ludwig Steindorff (Kiel), Peter Štih (Ljubljana)

Izvršna urednica za tuzemnu i inozemnu razmjenu / Executive Editor for Publications Exchange Kristina Milković

Tajnik uredništva / Editorial Board Assistant

Dejan Zadro

Adresa uredništva/Editorial Board address

Zavod za hrvatsku povijest, Filozofski fakultet Zagreb, Ivana Lučića 3, HR-10 000, Zagreb

Tel. ++385 (0)1 6120 150, 6120 158, faks ++385 (0)1 6156879

Časopis izlazi jedanput godišnje / The Journal is published once a year

Časopis je u digitalnom obliku dostupan na / The Journal in digital form is accessible at Portal znanstvenih časopisa Republike Hrvatske „Hrčak“ http://hrcak.srce.hr/radovi-zhp

Financijska potpora za tisak časopisa / The Journal is published with the support by

Ministarstvo znanosti, obrazovanja i športa Republike Hrvatske

Časopis je indeksiran u sljedećim bazama / The Journal is indexed in the following databases:

Directory of Open Access Journals, EBSCO, SCOPUS, ERIH PLUS 
Naslovna stranica

Iva Mandić

Grafičko oblikovanje i računalni slog

Marko Maraković

Lektura

Samanta Paronić

Tisak

Web2tisak, Zagreb

Naklada

250 primjeraka

Časopis je u digitalnom obliku dostupan na Portalu znanstvenih časopisa Republike Hrvatske ,Hrčak“ http://hrcak.srce.hr/radovi-zhp

The Journal is accessible in digital form at the Hrcak - Portal of scientific journals of Croatia http://hrcak.srce.hr/radovi-zhp 


\section{RADOVI 47}

\section{vol. 1}

ZaVoda za hrVAtSku poviJest FILOZOFskoga fakulteta SVeuČILIŠTA u Zagrebu 


\title{
Tematski blok / Themed issue
}

\section{TREĆOREDSKA GLAGOLJAŠKA TRADICIJA U EUROPSKOM KONTEKSTU TERTIARY GLAGOLITIC TRADITION IN EUROPEAN CONTEXT}

\author{
Radovi međunarodnoga znanstvenog skupa \\ održanoga 27. i 28. IX. 2013. na Hrvatskom katoličkom sveučilištu u Zagrebu \\ u organizaciji \\ Provincije franjevaca trećoredaca glagoljaša u Zagrebu, Hrvatskoga katoličkog \\ sveučilišta u Zagrebu, Filozofskoga fakulteta Sveučilišta u Zagrebu - Odsjek za \\ povijest, Filozofskoga fakulteta Sveučilišta u Splitu - Odsjek za povijest, Instituta \\ za povijest umjetnosti u Zagrebu i Staroslavenskoga instituta u Zagrebu \\ Proceedings of the International Scientific Conference \\ held on 27th and 28th September 2013 at the Catholic University of Croatia in Zagreb \\ and organized by \\ the Province of the Glagolitic Friars of the Third Order Regular, Catholic University \\ of Croatia in Zagreb, Faculty of Humanities and Social Sciences of the University \\ of Zagreb - Department of History, Faculty of Humanities and Social Sciences of \\ the University of Split - Department of History, Institute of Art History, \\ and Old Church Slavonic Institute
}

Gosti urednici / Guest editors

\author{
Ivan BOTICA \\ Tomislav GALOVIĆ \\ Kristijan KUHAR
}

